\title{
PENGARUH STRES KERJA TERHADAP KEPUASAN KERJA KARYAWAN DENGAN DUKUNGAN SOSIAL SEBAGAI VARIABEL MODERASI
}

\author{
Bagus Sanjaya \\ Universitas Negeri Surabaya \\ bagussanjayaaa@gmail.com
}

Abstract

\begin{abstract}
This research aims to examine and analyze the impact of work stress on job satisfaction with social support as a moderating variable. This research method is quantitative, using Simple Random Sampling for its sampling technique. There were 60 employees as samples-the data collected by observation, interviews, and questionnaires. The statistical analysis used in this study was descriptive analysis and data analysis by utilizing Partial Least Square (PLS) with SmartPLS 3.0 as the tool and Statistical Package for the Social Science (SPSS) software. The result shows that work stress has a negative and significant influence on job satisfaction. Work stress will result in a decrease in job satisfaction felt by employees. As well as social support did not moderate the relationship between work stress and job satisfaction. Social support does not decrease the impact of work stress on job satisfaction that occur within the company. The company should manage the work stress level to fulfil workers' job satisfaction and avert adverse effects to the company's activities.
\end{abstract}

Keywords: job satisfaction; social support; work stress.

\section{PENDAHULUAN}

COVID-19 (Corona Virus Disease-19) yang terjadi pada 2020 mengakibatkan seluruh orang di dunia untuk tetap berada di rumah agar terhindar dari penularan virus tersebut. Bagi sebagian orang yang harus meninggalkan rumah, wajib memberlakukan social distancing atau menjaga jarak antara satu sama lain dan tidak boleh membuat suatu gerombolan orang karena dikhawatirkan akan menimbulkan klaster. COVID-19 membuat ekonomi dunia berada di titik terendah yang dibuktikan dengan total pengangguran terus bertambah, industri jasa melemah, aktivitas manufaktur lesu, tahun buruk bagi perdagangan, hingga menyusutnya ekonomi global tahun 2020 (CNBC Indonesia, 2020). Banyak perusahaan harus mengurangi sejumlah karyawannya dengan tujuan untuk menghemat pengeluaran perusahaan dikarenakan turunnya pemasukan perusahaan, sehingga memberikan beban kerja yang lebih pada karyawan yang masih bertahan agar perusahaan tetap bisa survive semasa pandemi (CNBC Indonesia, 2020b). Selain itu, pandemi COVID-19 menimbulkan rasa stres, dilema, takut, dan putus asa pada seluruh orang (Kompas, 2020). Menurut Kusuma \& Soesatyo (2014), beban kerja mempunyai dampak positif dan signifikan bagi stres kerja, yang berarti saat beban kerja yang diberikan tinggi maka stres kerja yang terjadipun juga tinggi.

Stres kerja didefinisikan sebagai respon bahaya secara fisikal ataupun emosional yang terjadi saat tuntutan dari pekerjaan tidak sama dengan kemampuan, sumber ataupun kebutuhan dari karyawan. Dengan kata lain, stres merupakan suatu masalah serius baik secara fisik maupun emosional yang dapat memengaruhi kondisi karyawan itu sendiri (T \& Gupta, 2018).

Stres kerja memiliki dampak secara negatif dan signifikan bagi kepuasan kerja. Saat level stres kerja tinggi, tingkat kepuasan kerja karyawan rendah. Stres kerja yang terlalu berlebihan bisa memengaruhi keterampilan individu menghadapi lingkungan, kemudian akan mengganggu terlaksananya kegiatan dalam pekerjaannya dan membuatnya tidak maksimal dalam melakukan tugasnya, sehingga akan berdampak pada kepuasan kerjanya akan tidak terpenuhi (Suartana \& Dewi, 2020). Penelitian lain menunjukkan hasil yang berbeda. Sasuwe et al. (2018) membuktikan stres kerja tidak berdampak signifikan terhadap kepuasan kerja.

Kepuasan kerja ialah sebuah perilaku pegawai terhadap pekerjaan yang mempunyai hubungan dengan kondisi kerja, kerja sama antar pegawai, imbalan yang diperoleh, serta hal lain yang bersangkutan dengan faktor fisik dan psikologis (Hamali, 2018). Suparyadi (2015) menyatakan bahwa kepuasan 
Bagus Sanjaya. Pengaruh Stres Kerja terhadap Kepuasan Kerja Karyawan dengan Dukungan Sosial sebagai Variabel Moderasi

kerja pegawai dapat berdampak pada perilaku di tempat kerja, seperti memberikan saran untuk meningkatkan kualitas lingkungan pekerjaan atau organisasi, menghargai dan menyukai sesama rekan kerja maupun atasan. Sehingga kepuasan kerja dapat memberikan output yang berbeda, tergantung dari tingkat kepuasan kerja karyawan itu sendiri.

Akibat dari stres kerja yang memiliki dampak negatif bagi kepuasan kerja karyawan, diperlukannya faktor lain yang dapat menanggulangi masalah tersebut. Sumber-sumber positif dapat digunakan untuk mengurangi dampak negatif dari stres, salah satunya adalah dukungan sosial. Tingkat dukungan sosial dari administrators, supervisors, dan rekan kerja memengaruhi secara signifikan bagi kepuasan kerja karyawan (Lambert et al., 2016). Sultan \& Rashid (2015) menyebutkan bahwa dukungan sosial memediasi secara parsial terhadap korelasi antara stres dengan kepuasan kerja pegawai.

Objek penelitian ini adalah PT Adhi Persada Gedung cabang proyek Bess Mansion. Dari hasil observasi awal, perusahaan tersebut merupakan perusahaan penyedia jasa konstruksi spesialis gedung. Berdasarkan visi dari PT Adhi Persada Gedung, perusahaan ingin jadi perusahaan penyedia jasa konstruksi spesialis gedung yang professional dan berbudaya unggul untuk pertumbuhan yang berkelanjutan. PT Adhi Persada Gedung merupakan perusahaan yang besar dan sudah menyelesaikan banyak proyek-proyek gedung besar dan bertingkat. Dengan hanya menilik secara kasat mata, PT Adhi Persada Gedung memiliki tuntutan pekerjaan yang lebih terhadap para karyawannya. Berdasarkan hasil interview dan observasi dengan salah satu manajer bernama Bapak Yus, stres kerja juga sedang terjadi di PT Adhi Persada Gedung cabang proyek Bess Mansion. Hal ini dikarenakan tuntutan pekerjaan yang terjadi di proyek tersebut harus mencapai target yang ditentukan. Belum lagi dengan kondisi pandemi COVID-19, di mana proyek tersebut terdapat banyak karyawan dan juga pekerja yang dapat menimbulkan kekhawatiran akan penularan virus corona.

Penelitian ini bertujuan untuk menemukan pengaruh stres kerja bagi kepuasan kerja karyawan dengan dukungan sosial sebagai variabel moderasi.

\section{KAJIAN PUSTAKA DAN PENGEMBANGAN HIPOTESIS}

\section{Stres Kerja}

Stres adalah istilah umum yang mewakili pengalaman di mana tuntutan lingkungan dari suatu situasi melebihi persepsi psikologis individu dan kemampuan fisiologis untuk mengatasinya secara efektif (Cohen et al., 2016). Stres ialah sebuah situasi yang menyebabkan ketegangan yang bisa berdampak pada emosi, cara bernalar, dan kondisi seseorang (Wulan et al., 2018). Menurut Rivai (2013), stres kerja ialah sebuah situasi yang menimbulkan adanya ketidakseimbangan antara fisik dengan psikis yang dapat berdampak pada emosi, cara bernalar, dan juga kondisi seorang pekerja. Stres kerja dimaknai menjadi respon bahaya secara fisikal ataupun emosional yang terjadi saat tuntutan dari pekerjaan tidak pas dengan kemampuan, sumber ataupun kebutuhan dari karyawan ( $\mathrm{T} \&$ Gupta, 2018).

Penelitian ini menggunakan indikator untuk mengukur stres kerja menurut Luthans (2006) yakni sebagai berikut. (1) Stressor ekstra organisasi, merupakan faktor sebab stress yang muncul dari eksternal kelompok. (2) Stressor organisasi, merupakan faktor stress yang muncul dari kelompok tempat pekerja bekerja. (3) Stressor kelompok, merupakan faktor stress yang muncul dari organisasi kerja yang sering berkomunikasi dengan pekerja. (4) Stressor individual, merupakan faktor stress yang muncul dari personal di dalam kelompok.

\section{Kepuasan Kerja}

Menurut Bhastary (2020), kepuasan kerja adalah suatu sikap, perilaku dan sudut pandang seorang pekerja saat melaksanakan tugas kerjanya. Kepuasan kerja bersifat individualis. Kepuasan kerja antar pekerja akan memiliki kepuasan kerja yang berbeda yang di mana kepuasan kerja tersebut akan memengaruhi pekerjaan yang dilaksanakan pekerja tersebut. Menurut Kesawa et al. (2019), kepuasan kerja merupakan perilaku seseorang kepada pekerjaannya yang menunjukkan perbedaan antara apresiasi-apresiasi yang diperoleh oleh karyawan tersebut dengan yang mereka harapkan. Menurut Ali 
\& Wardoyo (2021), kepuasan kerja ialah energi positif yang diberikan oleh karyawan kepada pekerjanya yang disebabkan oleh hasil evaluasi kerja.

Penelitian ini menggunakan indikator kepuasan kerja menurut Setyanti (2009:29) sebagai berikut. (1) Pembayaran, misalnya gaji atau upah, karyawan mengharapkan sistem pemberian gaji dan kebijaksanaan promosi yang dipersepsikan sebagai adil, jelas dan selaras dengan pengaharapannya. (2) Beban kerja, karyawan lebih suka jika pekerjaannya adalah pekerjaan yang dapat memberikan kesempatan untuk memaksimalkan ketrampilan dan keunggulannya, kebebasan dan timbal balik mengenai betapa baik mereka saat kerja. (3) Rekan kerja, kebanyakan karyawan memerlukan rekan kerja untuk kebutuhannya berinteraksi sosial. (4) Promosi pekerjaan, promosi terjadi ketika pekerjaan seseorang berpindah kepada posisi yang lebih tinggi jenjang organisasional dan tanggung jawabnya. (5) Kepenyeliaan (supervisor), supervisor memiliki dampak penting bagi manajemen. Supervisor ini berhubungan dengan kerja dalam melakukan pekerjaannya.

\section{Dukungan Sosial}

Menurut Purdini et al. (2016), dukungan sosial merupakan sumber daya yang mendukung seorang individu dalam menghadapi sesuatu peristiwa yang menekan yang bisa memengaruhi kesehatan dan kesejahteraan individu yang bisa berasal dari keluarga (orang tua, anak, teman) dan lingkungan pekerjaan (rekan kerja, atasan, bawahan). Dukungan sosial dapat diartikan sebagai bantuan fisik, emosional, informasional, dan instrumental yang berasal dari lingkungan sosial seseorang tersebut ( $\mathrm{Lu}$ et al., 2018). Menurut Ivancevich (2007), dukungan sosial merupakan perasaan nyaman, bantuan, atau informasi yang diperoleh individu dengan cara melalui kontak formal atau informal dengan individu atau kelompok. Dukungan sosial dapat berwujud dukungan emosional, dukungan penilaian, dukungan informasi. Di lingkungan kerja, dukungan sosial dapat berasal dari partner kerja, staff, pimpinan, pelanggan, dan seseorang di luar tempat kerja yang dikenal oleh karyawan. Penelitian ini menggunakan indikator dukungan sosial menurut Moeller \& Chung-Yan (2013) meliputi (1) dukungan sosial dari teman kerja, (2) dukungan sosial dari pimpinan, (3) dukungan sosial dari teman hidup/keluarga

\section{Hubungan antar Variabel}

Stres kerja adalah sebuah respon bahaya yang terjadi saat tuntutan dari pekerjaan tidak sesuai dengan kemampuan karyawan ( $\mathrm{T} \&$ Gupta, 2018). Kepuasan kerja merupakan suatu sikap ataupun rasa kepuasan dan ketidakpuasan terhadap hasil pekerjaannya (Dewi \& Bagia, 2018). Respon bahaya yang ditimbulkan oleh stres kerja tersebut dapat menciptakan situasi-situasi yang penuh dengan tekanan bagi karyawan sehingga memberikan dampak bagi kepuasan kerja karyawan. Hal tersebut dikuatkan oleh Suartana \& Dewi (2020), Permatasari \& Prasetio (2018), Paramita \& Sendow (2016), Ridho \& Susanti (2019), Linda et al. (2016), Bhastary (2020), dan Dewi et al. (2018) tentang dampak stres kerja bagi kepuasan kerja. Stres kerja berdampak secara negatif dan signifikan bagi kepuasan kerja pekerja. Dengan kata lain, ketika stres kerja pekerja meningkat, kepuasan kerja akan menurun. Berbeda dengan hasil penelitian Sasuwe et al. (2018) dan Hanim (2016), stres kerja tidak berpengaruh terhadap kepuasan kerja.

\section{H1: Stres kerja berpengaruh secara negatif terhadap kepuasan kerja.}

Berdasarkan hasil penelitian Suartana \& Dewi (2020), Permatasari \& Prasetio (2018), Paramita \& Sendow (2016), Ridho \& Susanti (2019), Linda et al. (2016), Bhastary (2020), dan Dewi et al. (2018), stres kerja dapat memberikan pengaruh negatif bagi kepuasan kerja, maka dibutuhkan variabel yang dapat menanggulangi hal tersebut, salah satunya yaitu dengan dukungan sosial. Lee et al. (2015) menyebutkan bahwa dukungan dari rekan kerja memiliki efek secara langsung dan juga memoderasi dua indikator yaitu kepuasan kerja dengan tingkat stres. Korelasi antara stres kerja dengan kepuasan kerja pekerja dimediasi secara parsial oleh dukungan sosial (Sultan \& Rashid, 2015). Roxana (2013) mengkonfirmasi peran mediasi dari dukungan rekan kerja dan supervisor dengan kepuasan diantara emotional demands dan kepuasan kerja karyawan. Lambert et al. (2016) menyebutkan semakin tinggi tingkat dukungan sosial administrators, supervisors, dan rekan kerja memengaruhi secara signifikan 
Bagus Sanjaya. Pengaruh Stres Kerja terhadap Kepuasan Kerja Karyawan dengan Dukungan Sosial sebagai Variabel Moderasi

bagi kepuasan kerja pekerja. Sebagai contoh lain selain karyawan, Lu et al. (2018) menyebutkan bahwa dukungan sosial memediasi dan memoderasi pengaruh parenting stress terhadap life satisfaction pada orang tua yang memiliki anak. Namun menurut Rifai (2017), dukungan sosial tidak memoderasi hubungan stres kerja terhadap kepuasan kerja.

H2: Dukungan sosial memoderasi hubungan antara stres kerja terhadap kepuasan kerja.

Hubungan antar variabel dalam penelitian ini juga digambarkan dalam kerangka penelitian di Gambar 1.

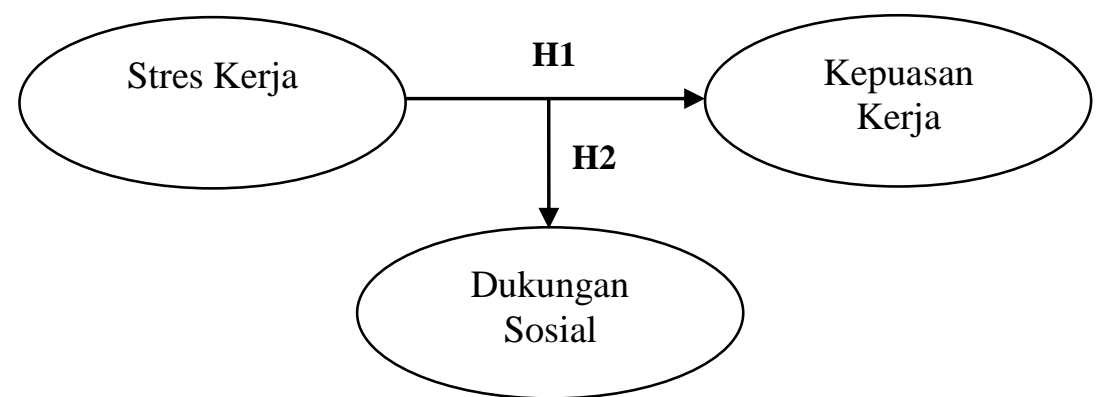

Gambar 1. KERANGKA PENELITIAN

\section{METODOLOGI PENELITIAN}

Jenis pendekatan pada penelitian ini menggunakan metode kuantitatif. Data yang digunakan pada penelitian ini adalah data primer yang diperoleh secara langsung dari sumber informasi yaitu responden yang kemudian digunakan sebagai sampel, dan data sekunder yang diperoleh secara tidak langsung yang digunakan sebagai pendukung dari data primer. Pengumpulan data dilakukan dengan menggabungkan tiga teknik pengumpulan data yaitu metode observasi, wawancara, dan kuesioner.

Skala yang digunakan untuk melakukan pengukuran ketika menyusun kuisioner adalah skala Likert yang digunakan untuk mengukur perilaku, asumsi, dan sudut pandang seorang individu maupun sekelompok individu perihal fenomena sosial, dengan rentang skala 1 (sangat tidak setuju) sampai skala 5 (sangat setuju) (Sugiyono, 2015).

Populasi pada penelitian ini adalah karyawan PT Adhi Persada Gedung cabang proyek Bess Mansion sejumlah 70 orang. Metode sampling yang dipakai adalah simple random sampling. Metode pengambilan sampel menggunakan rumus slovin yang memberikan hasil 60 karyawan sebagai sampel penelitian.

Teknik analisis yang dipakai adalah analisis statistik deskriptif dan analisis Partial Least Square (PLS) dengan memakai teknik Structural Equation Modeling (SEM) dan Uji Hipotesis dengan memakai software SmartPLS 3.0 dan Statistical Package for the Social Science (SPSS).

\section{HASIL DAN PEMBAHASAN}

\section{Hasil Uji Validitas}

Menurut Sugiyono (2015:121), uji validitas digunakan untuk mengukur dapat tidaknya instrumen tersebut untuk mengukur apa yang seharusnya diukur. Dengan menggunakan software SmartPLS3.0, indikator dinyatakan valid apabila memiliki korelasi lebih dari 0,70. Tapi untuk beberapa loadings dengan nilai 0,50 hingga 0,60 masih bisa diterima. Hasil uji validitas pada variabel stres kerja sejumlah 12 item pernyataan menghasilkan 2 item pernyataan terbukti tidak valid dan 10 item pernyataan terbukti valid. Hasil pengujian validitas di variabel kepuasan kerja sejumlah 9 item pernyataan menghasilkan 3 item pernyataan terbukti tidak valid, dan 6 item pernyataan terbukti valid. Hasil uji validitas pada variabel stres kerja sejumlah 9 item pernyataan menghasilkan 2 item pernyataan terbukti tidak valid, dan 7 item pernyataan terbukti valid. 


\section{Hasil Uji Reliabilitas}

Menurut (Ghozali, 2018:45) reliabilitas adalah alat yang digunakan untuk mengukur sebuah kuesioner yang merupakan indikator dari variabel atau konstruk. Penelitian ini menggunakan composite reliability untuk menguji nilai reliabilitas setiap indikator yang digunakan untuk mengukur sebuah konstruk. Konstruk dinyatakan reliabel apabila hasil dari composite reliability di atas 0,60. Berdasarkan tabel 1, hasil composite reliability seluruh variabel >0,60. Maka model variabel dinyatakan reliabel.

Tabel 1.

\section{COMPOSITE RELIABILITY}

\begin{tabular}{lcc}
\hline \multicolumn{1}{c}{ Variabel } & Composite Reliability & Keterangan \\
\hline Dukungan Sosial & 0,888 & Reliabel \\
Kepuasan Kerja & 0,852 & Reliabel \\
Stres Kerja & 0,911 & Reliabel \\
\hline
\end{tabular}

Sumber: Output SmartPLS 3.0 (2021, data diolah)

\section{Hasil Analisis Statistik Deskriptif}

Hasil jawaban responden terhadap pernyataan kuesioner tentang stres kerja, kepuasan kerja, dan dukungan sosial menghasilkan nilai rata-rata (mean) dari nilai total jawaban. Nilai mean dari variabel stres kerja sebesar 36, variabel kepuasan kerja sebesar 27, variabel dukungan sosial sebesar 27. Stres kerja yang terjadi tergolong dalam kategori sedang, kepuasan kerja termasuk dalam kategori tinggi, sedangkan dukungan sosial tergolong tinggi.

\section{Hasil Analisis R-Square}

Hasil analisis R-square sebesar 0,387 yang maknanya stres kerja dan dukungan sosial memiliki pengaruh sejumlah 38,7\% pada kepuasan kerja dan sebesar 61,3\% lainnya dipengaruhi oleh sebab lainnya.

\section{Hasil Uji T (Signifikansi)}

Pengujian ini mempunyai tujuan untuk mengetahui ada tidaknya pengaruh yang signifikan antar variabel. Pengaruh antar variabel dinyatakan signfikan jika nilai t hitung lebih besar dari nilai t-tabel yaitu 1,96 atau $\mathrm{P}$ value lebih kecil dari 0,05. Hasil pengujian ini diperoleh berdasarkan dari hasil Path Coefficient pada Inner Model.

Berdasarkan tabel 2, pengaruh dukungan sosial bagi kepuasan kerja memiliki nilai path sejumlah 0,421, hasil T-statistics sejumlah 4,760, serta P Value sejumlah 0,000. Perbandingan T-statistics dengan t-tabel adalah 4,760 > 1,96. Sehingga pengaruh dukungan sosial bagi kepuasan kerja adalah positif dan signifikan. Kemudian, dampak stres kerja bagi kepuasan kerja mempunyai hasil path sejumlah -0,344, hasil T-statistics sejumlah 4,589, P Value sejumlah 0,000. Perbandingan T-statistics dengan hasil t-tabel adalah 4,589 > 1,96. Sehingga, stres kerja berpengaruh negatif dan signifikan bagi kepuasan kerja. Dengan kata lain, hipotesis 1 terbukti.

Tabel 2.

HASIL PATH COEFFICIENT

\begin{tabular}{lllll}
\hline \multicolumn{1}{c}{ Hubungan } & Original Sample & T-Statistics & P Values & \multicolumn{1}{c}{ Keterangan } \\
\hline Dukungan Sosial $\rightarrow$ Kepuasan Kerja & 0.421 & 4,760 & 0,000 & Signifikan \\
Stres Kerja $\rightarrow$ Kepuasan Kerja & $-0,344$ & 4,589 & 0,000 & Signifikan \\
Stres Kerja * Dukungan Sosial $\rightarrow$ & -0.055 & 0,853 & 0,394 & Tidak \\
Kepuasan Kerja & & & & Signifikan \\
\hline
\end{tabular}

Sumber: Ouput SmartPLS 3.0 (2021, data diolah)

Pengaruh stres kerja yang moderasi oleh dukungan sosial bagi kepuasan kerja memiliki nilai path sebesar -0,055, hasil T-statistics sejumlah 0,853, serta P Value sejumlah 0,394. Perbandingan T- 
Bagus Sanjaya. Pengaruh Stres Kerja terhadap Kepuasan Kerja Karyawan dengan Dukungan Sosial sebagai Variabel Moderasi

statistics dengan t-tabel adalah jika $0,853<1,96$. Sehingga variabel stres kerja yang dimoderasi dengan dukungan sosial tidak berdampak secara signifikan bagi kepuasan kerja atau dengan makna lain hubungan antara stres kerja dengan kepuasan kerja tidak dimoderasi oleh variabel dukungan sosial. Artinya, penelitian ini gagal membuktikan hipotesis 2 .

\section{Pengaruh Stres Kerja terhadap Kepuasan Kerja}

Berdasarkan hasil pengujian hipotesis 1, stres kerja berdampak secara negatif signifikan bagi kepuasan kerja. Maka semakin tinggi stres kerja yang terjadi pada karyawan, maka semakin rendah kepuasan kerja karyawan atau menurunnya tingkat kepuasan kerja. Begitupun sebaliknya, semakin kecil tingkat stres kerja yang terjadi, maka makin meningkat pula tingkat kepuasan kerja pada pekerja. Hasil tersebut sejalan dengan hasil penelitian (Suartana \& Dewi, 2020) dan (Permatasari \& Prasetio, 2018).

Hasil ini juga selaras dengan hasil wawancara dengan Bapak Yus yang menyebutkan bahwa seringkali karyawan merasakan stres kerja dikarenakan tuntutan pekerjaan yang mengharuskan karyawan mencapai target yang ditentukan, sehingga menimbulkan keluh kesah karyawan akan pekerjaannya. Hal tersebut menandakan penurunan kepuasan kerja karyawan akan pekerjaan mereka dikarenakan stres kerja yang dialaminya. Hal ini diperparah oleh terjadinya pandemi COVID-19, mengingat penyebaran dan penularan akan virus tersebut sangat amat cepat, dapat membuat karyawan semakin takut akan tertular virus corona. Ketika rasa takut tersebut tidak bisa diolah dengan baik dan hingga menimbulkan paranoid, dapat memperparah terjadinya stres kerja dan akan semakin menurunkan tingkat kepuasan kerja.

Jika fenomena stres kerja yang terjadi tidak bisa teratasi dengan baik, dapat memunculkan masalahmasalah lain dari sisi karyawan itu sendiri maupun dari sisi perusahaan. Dari sisi karyawan itu sendiri, pekerjaan akan terganggu dikarenakan karyawan tidak bisa fokus saat melaksanakan tugasnya, dan kemungkinan terburuknya bisa memunculkan potensi kecelakaan kerja, mengingat lingkungan kerja pekerja adalah proyek pembangunan gedung bertingkat dengan resiko kecelakaan kerja yang cukup tinggi. Serta bisa menumbuhkan niat untuk pindah/keluar dari perusahaan yang dapat mengganggu aktifitas perusahaan sehingga tidak tercapainya target perusahaan yang dapat berakibat kerugian.

\section{Pengaruh Stres Kerja yang Dimoderasi oleh Dukungan Sosial terhadap Kepuasan Kerja}

Berdasarkan hasil pengujian hipotesis 2, variabel stres kerja yang dimoderasi oleh dukungan sosial tidak berdampak secara signifikan bagi kepuasan kerja atau dengan kata lain variabel dukungan sosial tidak memoderasi korelasi antara stres kerja bagi kepuasan kerja. Hasil tersebut sejalan dengan hasil penelitian Rifai (2017).

Berdasarkan hasil analisis deskriptif, tingkat stres kerja yang terjadi pada karyawan berada di kategori sedang, dapat diartikan karyawan tidak mengalami stres yang akut, sehingga efek moderasi dari dukungan sosial tidak terlalu kuat. Efek moderasi dari dukungan sosial bergantung pada akut atau tidaknya situasi stres kerja yang dialami oleh pekerja (Rifai, 2017). Hal ini dikuatkan oleh hasil interview dengan Bapak Yus jika karyawan tidak mengalami stres kerja yang sangat akut yang dapat mengganggu kinerja dari karyawan itu sendiri, hanya saja karyawan seringkali mengalami cemas dan gelisah pada saat pekerjaan mereka belum selesai.

Mengacu pada hasil analisis deskriptif, tingkat dukungan sosial dan kepuasan kerja yang terjadi pada karyawan PT Adhi Persada Gedung cabang proyek Bess Mansion berada pada kategori tinggi. Dapat dinyatakan jika pada penelitian ini dampak dari stres kerja bagi kepuasan kerja tidak dimoderasi atau diturunkan oleh dukungan sosial, dikarenakan meskipun dengan terjadinya stres kerja yang tergolong sedang, kepuasan kerja karyawan masih tetap tinggi. Kepuasan kerja yang tinggi itu juga dipengaruhi oleh tingginya tingkat dukungan sosial yang terjadi yang dibuktikan dengan hasil path coefficient pada tabel 2. yang menyatakan bahwa dukungan sosial berdampak secara positif dan signifikan bagi kepuasan kerja. Semakin besar dukungan sosial yang terjadi, maka semakin besar pula tingkat kepuasan kerja pekerja. Hasil ini juga dikuatkan dari hasil penelitian Purdini et al. (2016) dan Roxana (2013) yang menyatakan jika dukungan sosial berdampak secara positif dan signifikan. 
Tujuan yang ingin digapai oleh perusahaan adalah tingkat kepuasan kerja karyawan yang tinggi. Berdasarkan hasil analisis deskriptif, kepuasan kerja yang terjadi termasuk pada kategori tinggi, dapat dikatakan tujuan tersebut telah tercapai. Sehingga tugas perusahaan adalah mengelola stres kerja karyawan dari sedang menjadi rendah. Tingkat stres kerja pada karyawan dapat menjadi faktor yang akan menurunkan kepuasan kerja karyawan apabila perusahaan tidak dapat mengelola tingkat stres kerja pada karyawan. Menurut Suryani \& Yoga (2018), strategi untuk menangani stres kerja yang dapat diterapkan pada perusahaan adalah penetapan tata pelaksanaan kesehatan dan kesejahteraan pekerja, gaya manajemen (seperti keterbukaan dan komunikasi yang baik ke seluruh permasalahan yang dihadapi pekerja), manajemen perubahan (sadar akan perubahan yang akan datang), dan kegiatan pelatihan tentang cara mengelola stres kerja.

\section{KESIMPULAN}

Berdasarkan hasil penelitian, dapat disimpulkan bahwa stres kerja mempunyai dampak negatif dan signifikan bagi kepuasan kerja karyawan di PT Adhi Persada Gedung cabang Proyek Bess Mansion, sehingga hipotesis 1 diterima. Ketika tingkat stres kerja naik, maka dapat menimbulkan turunnya tingkat kepuasan kerja, begitupun sebaliknya. Hubungan antara stres kerja dengan kepuasan kerja karyawan di PT Adhi Persada Gedung cabang Proyek Bess Mansion tidak dimoderasi oleh dukungan sosial, maka hipotesis 2 ditolak. Tingkat stres kerja yang terjadi pada karyawan masih pada kategori sedang, dan tingkat kepuasan kerja karyawan berada pada kategori tinggi, sehingga meskipun terjadi stres kerja, karyawan tetap merasakan kepuasan kerja walaupun tanpa adanya pengaruh dukungan sosial. Melihat stres kerja yang terjadi berada pada kategori sedang, maka tugas perusahaan adalah mengelola stres kerja yang terjadi agar bisa menurun dari sedang menjadi rendah. Ketika stres kerja tidak dapat dikelola dengan baik, bisa berpotensi untuk menurunkan kepuasan kerja karyawan yang kemudian akan memengaruhi kegiatan perusahaan. Kemudian, disarankan bagi perusahaan untuk melakukan pertimbangan ulang untuk menghitung beban kerja pada karyawan, mengingat kegiatan usaha dari perusahaan adalah proyek pembangunan yang dimana kebanyakan karyawan bekerja di lapangan yang memiliki beban kerja cukup tinggi. Ketika beban kerja terlalu besar, maka dapat memicu timbulnya stres kerja yang berakibat pada penurunan kepuasan kerja. Penelitian ini terbatas dilakukan pada perusahaan yang bergerak pada bidang proyek pembangunan. Penelitian selanjutnya dapat melakukan penelitian pada bidang lainnya seperti perusahaan di bidang makanan/minuman, perusahaan start up, perusahaan online shop, ataupun pada UMKM. Penelitian selanjutnya juga dapat melibatkan variabel kelelahan kerja, kesehatan, dan work-life balance.

\section{DAFTAR PUSTAKA}

Ali, F., \& Wardoyo, D. T. W. (2021). Pengaruh Self Efficacy terhadap Kinerja Karyawan dengan Kepuasan Kerja sebagai Variabel Intervening (Studi PT Ultrajaya Milk Industry, Tbk Surabaya Bagian Marketing. Jurnal Ilmu Manajemen, 9(1), 367-379. https://journal.unesa.ac.id/index.php/jim/article/view/11678

Bhastary, M. D. (2020). Pengaruh Etika Kerja dan Stres Kerja terhadap Kepuasan Kerja Karyawan. Maneggio: Jurnal Ilmiah Magister Manajemen, 3(2), 160-170. https://doi.org/10.31227/osf.io/z7mab

CNBC Indonesia. (2020). Ini 7 Bukti COVID-19 telah bikin Ekonomi Dunia Hancur Lebur. https://www.cnbcindonesia.com/news/20200425183739-4-154449/ini-7-bukti-covid-19-telahbikin-ekonomi-dunia-hancur-lebur, diakses pada 4 November 2020

CNBC Indonesia. (2020b). Survei: Karena Covid-19, 35\% Pekerja di Indonesia Kena PHK. https://www.cnbcindonesia.com/news/20201007145144-4-192535/survei-karena-covid-19-35pekerja-di-indonesia-kena-phk, diakses pada 3 Juli 2021

Cohen, S., Gianaros, P. J., \& Manuck, S. B. (2016). A Stage Model of Stress and Disease. 
Bagus Sanjaya. Pengaruh Stres Kerja terhadap Kepuasan Kerja Karyawan dengan Dukungan Sosial sebagai Variabel Moderasi

Perspectives on Psychological Science, 11(4), 456-463. https://doi.org/10.1177/1745691616646305

Dewi, Bagia, \& Jana. (2018). Pengaruh Stres Kerja dan Kepuasan Kerja terhadap Kinerja Karyawan pada Bagian Tenaga Penjualan UD Surya Raditya Negara. Bisma: Jurnal Manajemen, 4(2), $154-161$.

Ghozali, I. (2018). Aplikasi Analisis Multivariate dengan Program IBM SPSS 25. Semarang: Badan Penerbit Undip.

Hamali, A. Y. (2018). Pemahaman Manajemen Sumber Daya Manusia. Yogyakarta: Buku Seru.

Hanim, M. L. (2016). Pengaruh Stres Kerja terhadap Kepuasan Kerja serta dampaknya pada Kinerja Karyawan Hull Construction Di PT Dok dan Perkapalan Surabaya. Jurnal Ilmu Manajemen (JIM), 4(3), 1-10.

Ivancevich, J. M. (2007). Perilaku dan Manajemen Organisasi. Jakarta: Erlangga.

Jawa Pos. (2020). Klaster Baru, Perkantoran Sumbang Kasus Covid Tertinggi. https://radarsurabaya.jawapos.com/read/2020/09/24/215659/klaster-baru-perkantoran-sumbangkasus-covid-tertinggi. diakses pada 4 November 2020

Kesawa, A. H., Fazlurrahman, H., Fatmawati, I. K., Puspitasari, D. P., \& Prastyo, B. (2019). The Effect of Psychological Well-Being and Psychological Empowerment on Job Satisfaction in Intitusion X. International Journal of Advances in Management and Economics, 8(6), 11-15. https://doi.org/10.31270/ijame/v08/i06/2019/2

Kompas. (2020). Bagaimana Dampak Stres Pandemi Corona pada Kesehatan Mental dan Fisik?. https://health.kompas.com/read/2020/05/10/190700368/bagaimana-dampak-stres-pandemicorona-pada-kesehatan-mental-dan-fisik-?page=all. diakses pada 4 November 2020

Kusuma, A. A., \& Soesatyo, Y. (2014). Pengaruh Beban Kerja terhadap Stres Kerja dan dampaknya terhadap Kinerja Karyawan. Jurnal Ilmu Manajamen, 2(2), 375-386.

Lambert, E. G., Minor, K. I., Wells, J. B., \& Hogan, N. L. (2016). Social Support's Relationship to Correctional Staff Job Stress, Job Involvement, Job Satisfaction, and Organizational $\begin{array}{lllll}\text { Commitment. Social } & \text { Science } & \text { Journal, } & 53(1), & 22-32 .\end{array}$ https://doi.org/10.1016/j.soscij.2015.10.001

Lee, S., Yun, T., \& Lee, S. Y. (2015). Moderating Role of Social Support in the Stressor-Satisfaction Relationship: Evidence from Police Officers in Korea. International Review of Public Administration, 20(1), 102-116. https://doi.org/10.1080/12294659.2014.982271

Linda, Y., Mintarti, S., Ekonomi, F., \& Mulawarman, U. (2016). Pengaruh Stress Kerja terhadap Kepuasan Kerja dan Intensi Meninggalkan Organisasi. JIMM: Jurnal Ilmu Manajemen Mulawarman, 1(1), 23-29.

Lu, M. H., Wang, G. H., Lei, H., Shi, M. L., Zhu, R., \& Jiang, F. (2018). Social Support as Mediator and Moderator of the Relationship Between Parenting Stress and Life Satisfaction among the Chinese Parents of Children with ASD. Journal of Autism and Developmental Disorders, 48(4), 1181-1188. https://doi.org/10.1007/s10803-017-3448-y

Luthans, F. (2006). Perilaku Organisasi 10th. Edisi Indonesia. Yogyakarta: Andi.

Moeller, C., \& Chung-Yan, G. A. (2013). Effects of Social Support on Professors' Work Stress. 
International Journal of Educational Management, 27(3), 188-202. https://doi.org/10.1108/09513541311306431

Paramita, L., \& Sendow, G. (2016). Pengaruh Komunikasi Organisasi dan Stres Kerja terhadap Kepuasan Kerja serta dampaknya terhadap Kinerja Karyawan di Perusahaan Umum Bulog Divisi Regional Sulawesi Utara. Jurnal Penelitian Ekonomi, Manajemen, Bisnis Dan Akuntansi, 4(1), 131-142. https://doi.org/10.35794/emba.v4i1.11580

Permatasari, H. I., \& Prasetio, A. P. (2018). Pengaruh Stress Kerja terhadap Kepuasan Kerja pada PT Pikiran Rakyat Bandung. Jurnal Manajemen Dan Bisnis (Almana), 2(1), 227-249.

Purdini, N., Musadieq, M., \& Mayowan, Y. (2016). Pengaruh Stres Kerja, Konflik Kerja dan Dukungan Sosial terhadap Kepuasan Kerja (Studi pada Perawat di Rumah Sakit Handles Vereneging Amsterdam (HVA) Toeloengredjo Kabupaten Kediri). Jurnal Administrasi Bisnis S1 Universitas Brawijaya, 38(2), 131-140.

Ridho, M., \& Susanti, F. (2019). Pengaruh Stres Kerja dan Motivasi Kerja terhadap Kepuasan Kerja pada Karyawan Bank Mandiri Syariah Cabang Padang. https://doi.org/10.31227/osf.io/pa2cg

Rifai, M. A. (2017). Pengaruh Stres Kerja terhadap Kepuasan Kerja Karyawan dengan Dukungan Sosial sebagai Variabel Moderator Pada Pdam Surya Sembada Kota Surabaya. Jurnal Ilmu Manajemen (JIM), 5(3), 1-8.

Rivai, V. (2013). Manajemen Sumber Daya Manusia Untuk Perusahaan Dari Teori Ke Praktek. Jakarta: PT RajaGrafindo Persada.

Roxana, A.-C. (2013). Social Support as a Mediator Between Emotion Work and Job Satisfaction. Procedia - Social and Behavioral Sciences, 84, 601-606. https://doi.org/10.1016/j.sbspro.2013.06.611

Sasuwe, M., Tewal, B., Uhing, Y., Manajemen, J., Sam, U., \& Manado, R. (2018). Pengaruh Budaya Organisasi dan Stres Kerja terhadap Kepuasan Kerja dan Produktivitas Kerja Karyawan PT Air Manado. Jurnal EMBA: Jurnal Penelitian Ekonomi, Manajemen, Bisnis Dan Akuntansi, 6(4), 2408-2418. https://doi.org/10.35794/emba.v6i4.21009

Setyanti, S. W. L. H. (2009). Manajemen Sumber Daya Manusia 1. Jember: Jember University Press.

Suartana, I. P., \& Dewi, I. G. A. M. (2020). Pengaruh Stres Kerja, Beban Kerja, dan Konflik Pekerjaan Keluarga terhadap Kepuasan Kerja Karyawan Swiss Belinn Hotel. E-Jurnal $\begin{array}{lll}\text { Manajemen Universitas } \quad \text { Udayana, 8(3), } & \text { 863-883. }\end{array}$ https://doi.org/10.24843/ejmunud.2020.v09.i03.p03

Sugiyono. (2015). Metode Penelitian Kuantitatif, Kualitatif, dan R\&D. Bandung: Alfabeta.

Sultan, S., \& Rashid, S. (2015). Perceived Social Support Mediating the Relationship Between Perceived Stress and Job Satisfaction. I-Manager's Journal on Educational Psychology, 8(3).

Suparyadi. (2015). Manajemen Sumber Daya Manusia Menciptakan Keunggulan Bersaing Berbasis Kompetensi SDM. Yogyakarta: Andi.

Suryani, N. K., \& Maha Yoga, G. A. D. (2018). Konflik dan Stres Kerja dalam Organisasi. Widya Manajemen, 1(1), 99-113. https://doi.org/10.32795/widyamanajemen.v1i1.209

T, B., \& Gupta, K. (2018). Job Stress and Productivity: A Conceptual Framework. International Journal of Emerging Research in Management and Technology, 6(8), 393. 
Bagus Sanjaya. Pengaruh Stres Kerja terhadap Kepuasan Kerja Karyawan dengan Dukungan Sosial sebagai Variabel Moderasi

https://doi.org/10.23956/ijermt.v6i8.171

Wulan, P. A., Alam, S., \& Umar, F. (2018). Pengaruh Stres Kerja dan Motivasi terhadap Kepuasan dan Kinerja Karyawan PT PLN (Persero) Area Merauke. Hjabe, 1(2), 1-14. 